\title{
Hepatitis B core-related antigen (HBcrAg): an alternative to HBV DNA to assess treatment eligibility in Africa
}

\section{Author Names}

Yusuke Shimakawa ${ }^{1}$, Gibril Ndow ${ }^{2,3}$, Ramou Njie ${ }^{4}$, Harr Freeya Njai ${ }^{2, *}$, Kazuaki Takahashi ${ }^{5}$, Sheikh Mohammad Fazle Akbar ${ }^{6}$, Damien Cohen ${ }^{7}$, Shevanthi Nayagam ${ }^{3}$, Adam Jeng ${ }^{2}$, Amie Ceesay ${ }^{2,}$ Bakary Sanneh ${ }^{8,}$ Ignatius Baldeh ${ }^{8}$, Masayasu Imaizumi ${ }^{9}$, Kazushige Moriyama ${ }^{9}$, Katsumi Aoyagi ${ }^{9}$, Umberto D'Alessandro ${ }^{2}$, Shunji Mishiro ${ }^{5}$, Isabelle Chemin ${ }^{6}$, Maimuna Mendy ${ }^{10}$, Mark R. Thursz ${ }^{3}$, and Maud Lemoine ${ }^{3}$

${ }^{1}$ Unité d'Épidémiologie des Maladies Émergentes, Institut Pasteur, Paris, France

${ }^{2}$ Medical Research Council (MRC) Unit, The Gambia at the London School of Hygiene and Tropical Medicine, Fajara, The Gambia

${ }^{3}$ Department of Surgery and Cancer, Liver Unit, Imperial College London, UK

${ }^{4}$ The Gambia Hepatitis Intervention Study, IARC, c/o MRC Unit, Fajara, The Gambia

${ }^{5}$ Department of Medical Sciences, Toshiba General Hospital, Tokyo, Japan

${ }^{6}$ Department of Pathology, Ehime University Graduate School of Medicine, Ehime, Japan

${ }^{7}$ INSERM U1052, CNRS UMR5286, Centre de Recherche en Cancérologie, Université Claude Bernard, Lyon, France

${ }^{8}$ National Public Health Laboratory, Banjul, The Gambia

${ }^{9}$ Research and Development Division, Fujirebio Inc., Tokyo, Japan

${ }^{10}$ International Agency for Research on Cancer (IARC), Lyon, France

* Dr. Njai passed away. 


\section{Corresponding Author}

Yusuke Shimakawa

Unité d'Épidémiologie des Maladies Émergentes, Institut Pasteur, 25-28 rue du Dr Roux, 75015

Paris, France

Phone: +33(0) 140613887

Fax: +33(0) 145688876

Email: yusuke.shimakawa@pasteur.fr

\section{Summary}

Limited access to HBV DNA quantification represents a key barrier to global HBV elimination. We demonstrated high diagnostic accuracy of low-cost immunoassay, hepatitis B core-related antigen, to diagnose HBV DNA levels, and to select patients for antiviral therapy in Africa. 


\begin{abstract}
Background

To eliminate hepatitis B virus (HBV) infection, it is essential to scale up testing and treatment. However, conventional tools to assess treatment eligibility, particularly nucleic acid testing (NAT) to quantify HBV DNA, are hardly available and affordable in resource-limited countries. We therefore assessed the performance of novel immunoassay, hepatitis B core-related antigen (HBcrAg), as an inexpensive (US\$ < 10-15/assay) alternative to NAT to diagnose clinically important HBV DNA thresholds $(\geq 2,000 ; \geq 20,000$; and $\geq 200,000 \mathrm{IU} / \mathrm{ml})$, and select patients for antiviral therapy in Africa.

Methods
\end{abstract}

Using well-characterized cohort of treatment-naïve patients with chronic HBV infection in The Gambia, we evaluated the accuracy of serum HBcrAg to diagnose HBV DNA levels, and to indicate treatment eligibility determined by the American Association for the Study of Liver Diseases, based on the reference tests (HBV DNA, HBV e antigen (HBeAg), alanine transaminase (ALT), liver histopathology and/or FibroScan).

Results

A total of 284 treatment-naïve patients were included in the analysis. The area under the receiver operating characteristic curve (AUROC), sensitivity and specificity of serum HBcrAg were: 0.88 (95\% CI: $0.82-0.93), 83.3 \%$ and $83.9 \%$ to diagnose HBV DNA $\geq 2,000 \mathrm{IU} / \mathrm{ml}$; and $0.94(0.88$ 0.99), $91.4 \%$ and $93.2 \%$ for $\geq 200,000 \mathrm{IU} / \mathrm{ml}$. A simplified treatment algorithm using $\mathrm{HBcrAg}$ without HBV DNA showed high AUROC (0.91 (95\% CI: 0.88-0.95)) with a sensitivity of 96.6\% and specificity of $85.8 \%$.

Conclusions 
HBcrAg might be an accurate alternative to HBV DNA quantification as a simple and inexpensive tool to identify $\mathrm{HBV}$-infected patients in need of antiviral therapy in low- and middle-income countries.

\section{Keywords}

Hepatitis B core-related antigen; diagnostic test; validation studies; sensitivity and specificity;

Africa 


\section{Introduction}

Hepatitis B Virus (HBV) infection is a major global health problem, and recognized as a public health priority by the UN's Sustainable Development Goals. Subsequently, the World Health Organization (WHO) has developed a strategy to eliminate viral hepatitis by 2030, and one of the objectives is to globally increase the treatment uptake in people with chronic HBV infection (CHB) eligible for antiviral therapy from 8\% (2015) to 80\% (2030) [1]. To achieve this goal, it is critical to scale up screening for hepatitis B surface antigen (HBsAg), and clinical staging for those carrying HBsAg to assess treatment eligibility.

Quantification of HBV DNA constitutes an essential element of the clinical staging. The international guidelines define having high viremia $(\geq 2,000$ or $\geq 20,000 \mathrm{IU} / \mathrm{ml})$, in the presence of liver inflammation or fibrosis, to be one of the criteria to initiate antiviral therapy [2-5]. Moreover, the cut-off of $\geq 200,000 \mathrm{IU} / \mathrm{ml}$ is now used to select pregnant women for antiviral therapy to prevent mother-to-child transmission [2,3]. However, the vast majority (>95\%) of HBV-infected people live in low- and middle-income countries (LMICs) [6], and they have severely limited access to real-time polymerase chain reaction (PCR), a molecular assay to measure HBV DNA levels [7]. PCR is expensive, often restricted to large urban laboratories, and requires highly skilled laboratory technicians. Consequently, the WHO fully acknowledges an urgent need for a low-cost simple assay to measure HBV replication [8].

HBV core-related antigen ( $\mathrm{HBcrAg}$ ), consisting of three viral proteins (HBV core antigen, e antigen $(\mathrm{HBeAg})$ and a small core-related protein (p22cr)), is a novel serological marker of HBV replication [9]. Studies in Asia and Europe confirmed a close correlation between serum HBcrAg levels and serum HBV DNA levels in treatment-naïve patients with CHB [10-13]. Moreover, 
several studies also found a correlation of serum HBcrAg levels with intrahepatic covalently closed circular DNA (cccDNA), a transcriptional template of HBV $[10,11,14,15]$. Because this immunoassay is cheaper (US\$ $<10-15 /$ assay) and simpler than the conventional real-time PCR (US\$ 60-200/assay), this may represent an attractive alternative in LMICs. For hepatitis C virus (HCV) infection, a similar case has been already made. WHO now recommends the use of immunoassay ( $\mathrm{HCV}$ core antigen: $\mathrm{HCVcAg}$ ) to diagnose chronic $\mathrm{HCV}$ infection when $\mathrm{HCV}$ RNA PCR is not accessible [8], as $\mathrm{HCVcAg}$ is an accurate and inexpensive alternative to $\mathrm{HCV}$ RNA [16-18].

We assessed the performance of serum HBcrAg levels to diagnose three clinically important HBV DNA thresholds $(2,000,20,000$, and 200,000 IU/ml) in a well-characterized cohort of treatment-naïve CHB patients in The Gambia, West Africa. We also evaluated the associations of serum HBcrAg levels with significant liver fibrosis and inflammation, and the diagnostic accuracy of simplified treatment algorithms using HBcrAg as an alternative to HBV DNA, to correctly classify those eligible for antiviral therapy according to the conventional tests (HBV DNA, liver histology or FibroScan) as a reference.

\section{Materials and Methods}

\section{Study participants}

In 2011-2014, the Prevention of Liver Fibrosis and Cancer in Africa (PROLIFICA) Program recruited Gambian adults identified to carry HBsAg through community-based and blood bank screening using a rapid test (Determine, Alere, USA; or OnSite Combo Rapid Test, CTK Biotech, USA) $[19,20]$. In addition, the program also recruited symptomatic patients with chronic liver 
disease referred from health facilities throughout the country [21]. After informed consent, HBsAg-positive participants systematically underwent following clinical evaluation: fasting transient elastography (FibroScan 402, Echosens, France) [22], abdominal ultrasonography, hematology and biochemistry tests, HBeAg (ETI-EBK Plus, Diasorin, Italy), and HBV DNA (inhouse real-time PCR, limit of detection: $50 \mathrm{IU} / \mathrm{ml}$ ) [23]. All these laboratory analyses were performed locally. A subset of patients underwent liver biopsy [24]. Patients consecutively recruited from April 2012 to October 2013 were included in the current analysis. We excluded from the analysis participants with hepatocellular carcinoma (HCC), prior or current antiviral therapy for HBV, HIV co-infection, or missing virological data.

\section{Serum HBcrAg and HBsAg-HQ}

Patients' sera at the recruitment were stored at $-80{ }^{\circ} \mathrm{C}$ and shipped to Toshiba General hospital, Tokyo, Japan, where HBcrAg was quantified using a fully automated chemiluminescent immunoassay (CLIA) Lumipulse G600II (Fujirebio Inc, Tokyo, Japan) according to the manufacturer's instructions. The assay provided a reportable range of 3-7 log U/ml. Samples with HBcrAg > $7 \log \mathrm{U} / \mathrm{ml}$ were diluted and retested to quantify HBcrAg levels. HBsAg quantification was also made using a highly sensitive CLIA (HBsAg-HQ) with Lumipulse (limit of detection: $0.005 \mathrm{IU} / \mathrm{ml})$. These measurements were performed by staff blinded to the reference test results.

\section{International treatment guidelines}

The conventional treatment criteria established by the international guidelines are summarized in Supplementary Table 1. The American Association for the Study of Liver Diseases (AASLD), European Association for the Study of the Liver (EASL), and Asian Pacific Association for the

Study of the Liver (APASL) largely rely on three factors: levels of viral replication by HBV 
DNA PCR and/or HBeAg sero-status, degree of liver inflammation based on liver histopathology and/or alanine aminotransferase (ALT) levels, and fibrosis staging by histopathology or liver stiffness measurement [2-4]. For these criteria, significant liver fibrosis and cirrhosis were defined as Metavir $\geq \mathrm{F} 2$ and F4 in those who had biopsy, and liver stiffness $\geq 7.9 \mathrm{kPa}$ and $\geq 9.5$ $\mathrm{kPa}$ in those without biopsy, respectively [24]. Family history of HCC was not used to define treatment eligibility due to its poor ascertainment in The Gambia [25]. The WHO guidelines provides criteria for LMICs where HBV DNA testing is not available: cirrhosis, diagnosed by physical examination or aspartate aminotransferase (AST)-to-platelet ration index (APRI) >2.0; or persistently elevated ALT [5]. Because the cross-sectional data was used in this study, the eligibility was considered on a single time point. We used upper limits of normal for ALT specifically defined in each guidelines (Supplementary Table 2).

\section{Simplified treatment algorithms using HBcrAg}

We developed three simplified algorithms using HBcrAg (Models 1-3) to select HBsAg-positive patients for antiviral therapy. Model 1 is exactly same as the conventional criteria (AASLD, EASL and APASL) except for HBV DNA which was replaced by HBcrAg, and liver histopathology replaced by FibroScan. Optimal HBcrAg cut-off levels equivalent to HBV DNA thresholds of $\geq 2,000$ and $\geq 20,000 \mathrm{IU} / \mathrm{ml}$ were applied to these conventional criteria (Supplementary Table 3). Model 2 is a simple score based on HBcrAg and ALT alone, which is similar to the Treatment Eligibility in Africa for HBV (TREAT-B) scoring system composed of HBeAg and ALT levels [26]. In this Model, HBcrAg levels were dichotomized into high and low using an optimal threshold corresponding to HBV DNA levels of $\geq 2,000 \mathrm{IU} / \mathrm{ml}$. The total point was obtained by adding: HBcrAg score, low (0 point) or high (1); and ALT score, <20 IU/L (0 
point), $20-39$ (1), 40-79 (2) or $\geq 80$ (3). We considered the score of $\geq 2$ to indicate treatment eligibility [26]. Model 3 only used the dichotomized HBcrAg levels.

\section{Statistical analyses}

Quantified levels of serum HBV DNA, HBcrAg and HBsAg-HQ were $\log _{10}$ transformed, and the detection limit of each assay was assigned to samples with undetectable result. The correlation between these markers was assessed using Pearson's correlation coefficient. The correlation was also evaluated by $\mathrm{HBeAg}$ sero-status and viral genotypes. The capability of HBcrAg levels to correctly discriminate clinically important HBV DNA levels at three different cut-offs $(\geq 2,000$, $\geq 20,000$, and $\geq 200,000 \mathrm{IU} / \mathrm{ml}$ ) was evaluated by the receiver operating characteristic (ROC) curve. The optimal cut-offs for HBcrAg levels were selected to minimize the absolute difference between the sensitivity and specificity. The discrimination capabilities of HBcrAg levels were compared to those of HBsAg-HQ levels and HBeAg using area under the ROC curve (AUROC).

Among the virological factors (HBcrAg/HBsAg-HQ/HBeAg/HBV DNA/genotypes), those associated with liver inflammation (ALT $\geq 40 \mathrm{IU} / \mathrm{L})$ and significant fibrosis were identified using logistic regression. The factors significantly associated with the outcome in the univariable analyses $(\mathrm{p}<0.05)$ were further included in the multivariable model.

The performance of the simplified algorithms using HBcrAg (Models 1-3) was evaluated for each of the international guidelines (AASLD/EASL/APASL) as a reference. By using the AUROC, the discrimination capabilities of these algorithms were compared to the WHO criteria and TREAT-B. All the analyses were performed using Stata 13.0 (Stata Corporation, USA). The 
study was approved by the Gambian Government/MRC Joint Ethics Committee, and reported in accordance with the STARD [27].

\section{Results}

\section{Study participants}

Of $372 \mathrm{HBsAg}$-positive participants assessed for serum HBcrAg, 284 were included in the current analysis, after excluding 74 HCC cases, 9 HIV co-infection, and 5 with missing data (Figure 1). Their characteristics were described in Table 1. Median age was 36 years (interquartile range, IQR: 30-45), and 66\% were men. Positive $\mathrm{HBeAg}, \mathrm{HBcrAg}$, and HBV DNA were observed in $36(13 \%), 152(53 \%)$, and 165 patients (58\%), respectively. Median levels of HBsAg-HQ, HBcrAg, and HBV DNA were $3.6 \log \mathrm{IU} / \mathrm{ml}$ (IQR: 2.9-4.1), $4.0 \log \mathrm{U} / \mathrm{ml}$ (3.3-5.7), and $2.9 \log \mathrm{IU} / \mathrm{ml}$ (2.2-5.0), respectively, after excluding undetectable values. Majority harbored genotype E (84\%), followed by A (16\%). Proportion of patients eligible for antiviral therapy according to the AASLD, EASL, APASL, and WHO criteria for LMICs was $21 \%, 20 \%, 22 \%$, and $49 \%$, respectively.

\section{Correlation of HBcrAg with HBV DNA and HBsAg-HQ}

Correlation coefficient (r) was 0.75 ( $\mathrm{p}<0.0001)$ between HBcrAg and HBV DNA (Figure 2). The positive correlation was also confirmed in a subset of patients stratified by HBeAg sero-status $(\mathrm{r}=0.59, \mathrm{p}=0.0002$ for HBeAg-positive; and $\mathrm{r}=0.57, \mathrm{p}<0.0001$ for HBeAg-negative), and by genotype $(r=0.69, p<0.0001$ for genotype $A$; and $r=0.76, p<0.0001$ for genotype E) (Supplementary Figure 1). In contrast, the correlation was poor between HBcrAg and HBsAg- 
HQ ( $\mathrm{r}=0.22, \mathrm{p}=0.0003)$, and between HBsAg-HQ and HBV DNA ( $\mathrm{r}=0.16, \mathrm{p}=0.006)$ (Figure 2), irrespective of HBeAg positivity or viral genotype (Supplementary Figures 2-3).

\section{Performance of HBcrAg to diagnose viral load}

AUROC of HBcrAg to diagnose clinically important HBV DNA levels were: 0.88 (95\% CI: $0.82-0.93)$ for $\geq 2,000 \mathrm{IU} / \mathrm{ml}$; $0.92(0.87-0.98)$ for $\geq 20,000 \mathrm{IU} / \mathrm{ml}$; and $0.94(0.88-0.99)$ for $\geq 200,000 \mathrm{IU} / \mathrm{ml}$ (Table 2, Figure 3). The optimal cut-off of HBcrAg, sensitivity and specificity at each HBV DNA levels were: $3.6 \log \mathrm{U} / \mathrm{ml}, 83.3 \%$ and $83.9 \%$ to diagnose viremia $\geq 2,000 \mathrm{IU} / \mathrm{ml}$; $4.8 \log \mathrm{U} / \mathrm{ml}, 88.9 \%$ and $92.9 \%$ for $\geq 20,000 \mathrm{IU} / \mathrm{ml}$; and $5.3 \log \mathrm{U} / \mathrm{ml}, 91.4 \%$ and $93.2 \%$ for $\geq 200,000 \mathrm{IU} / \mathrm{ml}$.

In contrast to HBcrAg, HBsAg-HQ was not informative; the AUROC was 0.55 (95\% CI: 0.48$0.62), 0.53(0.45-0.61)$, and $0.56(0.47-0.66)$, for $\geq 2,000, \geq 20,000$ and $\geq 200,000 \mathrm{IU} / \mathrm{ml}$, respectively. AUROC of $\mathrm{HBeAg}$ was modest: 0.73 (95\% CI: 0.66-0.79) for $\geq 2,000 \mathrm{IU} / \mathrm{ml} ; 0.79$ (0.71-0.86) for $\geq 20,000 \mathrm{IU} / \mathrm{ml}$; and $0.83(0.75-0.91)$ for $\geq 200,000 \mathrm{IU} / \mathrm{ml}$. HBcrAg performed significantly better than HBsAg-HQ and HBeAg for all these HBV DNA thresholds (Table 2).

\section{Association of HBcrAg with ALT and fibrosis stage}

Box plots of HBcrAg according to ALT levels and fibrosis stage showed the positive correlation between these variables (Supplementary Figure 4). Of the virological factors, serum HBcrAg was the only variable independently associated with significant fibrosis (Table 3): compared to those with low HBcrAg levels ( $<3.6 \log \mathrm{U} / \mathrm{ml})$, its risk was 2.6 times (95\% CI: 1.2-5.8) higher in those with 3.6-5.3 $\log \mathrm{U} / \mathrm{ml}$, and 19.7 times (4.3-91.1) higher in those with $\geq 5.3 \log \mathrm{U} / \mathrm{ml}$ (adjusted $\mathrm{p}<0.001)$. Similarly, the statistically significant association with elevated ALT levels $(\geq 40 \mathrm{IU} / \mathrm{L})$ 
was only observed for HBcrAg after mutually adjusting for other viral factors. No statistically significant association was observed in the rest (HBsAg-HQ, HBeAg, HBV DNA and genotype). Without any significant change in the standard errors of regression coefficients of the virological factors between the crude and adjusted analyses, collinearity between these was unlikely.

\section{Performance of simplified treatment algorithms using HBcrAg}

AUROC of Model 1, the algorithm using HBcrAg, HBeAg, ALT, and FibroScan, without HBV DNA, to select patients eligible for antiviral therapy was 0.91 (95\% CI: 0.88-0.95) for AASLD, 0.91 (0.88-0.94) for EASL, and 0.96 (0.93-0.98) for APASL (Table 4, Figure 4). AUROC of Model 2, the simplified score based on HBcrAg and ALT levels was 0.90 (95\% CI: 0.85-0.94) for AASLD, 0.89 (0.84-0.94) for EASL, and 0.96 (0.94-0.98) for APASL. The AUROC did not significantly differ between the Model 1 and 2 across the guidelines (Supplementary Table 4). Model 3 which only uses HBcrAg did not perform well compared to the Model 1 and 2, with the AUROC varying between 0.80 and 0.84 .

TREAT-B, composed of ALT and HBeAg, showed AUROC of 0.87 (95\% CI: 0.81-0.92) for AASLD, 0.87 (0.81-0.93) for EASL, and 0.95 (0.93-0.98) for APASL. Compared to TREAT-B, the AUROC of Model 1 was marginally higher to diagnose AASLD ( $\mathrm{p}=0.09)$ and EASL ( $\mathrm{p}=0.07)$, but no difference was observed for APASL ( $\mathrm{p}=0.8$, Supplementary Table 4). The AUROC of Model 2 was significantly higher than that of TREAT-B to indicate AASLD criteria ( $\mathrm{p}=0.04$, Supplementary Table 4); however, there was no statistically significant difference for EASL $(\mathrm{p}=0.2)$ and APASL $(\mathrm{p}=0.8)$. The WHO criteria discriminated poorly: the AUROCs ranged between 0.73 and 0.80 , and were significantly lower than those of any of the algorithms presented, except for the Model 3 to diagnose APASL criteria. 


\section{Discussion}

In developed countries, HBcrAg has recently emerged as a novel tool to monitor HBV-infected patients under nucleos(t)ide analogues therapy [28]. Although persistence of HBV cccDNA in the nucleus of infected hepatocytes determines the chronicity of HBV infection and therefore represents a genuine marker of $\mathrm{HBV}$ replication, it is difficult to measure intrahepatic amount of cccDNA in routine clinical practice as this requires liver biopsy. Alternatively, serum HBV DNA is commonly used as a surrogate biomarker to evaluate HBV replication. However, its correlation with intrahepatic cccDNA is lost in patients treated with nucleos(t)ides analogues, because these drugs almost invariably lead to undetectable serum HBV DNA by blocking reverse transcription, while cccDNA still persists in majority of treated patients [29]. Another frequently used biomarker is serum HBsAg levels, but the degree of correlation with intrahepatic cccDNA is controversial, particularly for those negative for $\mathrm{HBeAg}$, since $\mathrm{HBsAg}$ can be derived not only from cccDNA, but also from HBV DNA integrated into the host genome [30]. In contrast, serum HBcrAg was found to be closely correlated with the amount of intrahepatic cccDNA before antiviral therapy $[10,11,14,15,31,32]$. After the initiation of nucleos(t)ides analogues, $\mathrm{HBcrAg}$ was found to reduce to a similar extent to the reduction in cccDNA $[10,11,14,31]$. Moreover, the transcriptional activity of intrahepatic cccDNA, represented by pregenomic RNA, has been also shown to be correlated with serum HBcrAg levels in patients with [33] or without nucleos(t)ides analogues [15]. Consequently, HBcrAg is now proposed as a novel marker for treatment response monitoring, and also as an endpoint for clinical trials of novel HBV drugs aiming at a functional cure of HBV infection [15,28,34]. 
In addition to its valuable and unique role in monitoring patients under HBV treatment, this study demonstrated for the first time that HBcrAg might be useful alternative to serum HBV DNA for the initial clinical assessment following HBsAg screening, to select patients in need of antiviral therapy in resource-limited settings. By comparing with serum HBV DNA PCR and treatment eligibility criteria centered by HBV viral load as references, we found (i) close correlation between HBcrAg and HBV DNA irrespective of HBeAg sero-status and HBV genotypes; (ii) excellent performance of $\mathrm{HBcrAg}$ to diagnose $\mathrm{HBV}$ DNA levels of $\geq 2,000, \geq 20,000$ and $\geq 200,000 \mathrm{IU} / \mathrm{ml}$; and (iii) high accuracy of simplified treatment algorithm using HBcrAg serology. Moreover, accumulating evidence suggest that HBcrAg may not only serve as an "alternative", but even "superior" to HBV DNA in identifying treatment-naïve patients at elevated risk of liver disease. Tada et al. found that HBcrAg was more accurate than HBV DNA to predict the development of $\mathrm{HCC}$ in a cohort of 1,031 treatment-naïve $\mathrm{CHB}$ patients after a median follow-up period of 10.7 years without antiviral treatment [35]. The same group also reported the superiority of $\mathrm{HBcrAg}$ to $\mathrm{HBV}$ DNA in predicting the progression to cirrhosis in patients without antiviral therapy [36]. Indeed, our study found that HBcrAg was independently associated with significant fibrosis and liver inflammation after adjusting for HBV DNA and $\mathrm{HBeAg}$, while other HBV markers were not. These results support that the risk stratification based on HBcrAg might be more accurate than using HBV DNA to assess eligibility for antiviral therapy in CHB patients, although this needs to be further assessed in a longitudinal cohort study.

Compared to the conventional molecular assay, serological assay is better adapted to LMICs with limited laboratory capacity because this may be less expensive and simpler to perform. However, recent advent of inexpensive automated point-of-care PCR assay, such as GeneXpert, may change the landscape of HBV diagnostics in LMICs. Further simplification of HBcrAg assay by 
developing a rapid diagnostic test with immunochromatographic lateral-flow assay will be feasible and possible at a lower cost than the point-of-care HBV DNA PCR. Lowering the limit of detection may not be the priority for such a test; for example, a rapid test detecting very high HBcrAg levels of $5.3 \log \mathrm{U} / \mathrm{ml}$ (equivalent to serum HBV DNA levels of 200,000 IU/ml in this study) should be enough to identify pregnant women who would benefit most from antiviral therapy to prevent mother-to-child transmission [37], given the high diagnostic sensitivity $(91.4 \%)$ and specificity $(93.2 \%)$ to indicate viral load threshold associated with immunoprophylaxis failure [38]. Moreover, the improvement in analytical sensitivity of $\mathrm{HBcrAg}$ has been recently made (unpublished data), and this may also contribute to the future development of rapid HBcrAg test to diagnose lower thresholds equivalent to serum HBV DNA levels of 2,000 or $20,000 \mathrm{IU} / \mathrm{ml}$.

As a limitation, HBcrAg was measured in a laboratory in Japan using stored sera. We will soon start a field study to validate $\mathrm{HBcrAg}$ in a resource-limited African laboratory. Whether HBcrAg can be used for identifying African patients in inactive phase who have poor prognosis remains unknown. This question will be addressed through a longitudinal follow-up of the PROLIFICA cohort in West Africa. Our study was limited to HBV genotypes A and E, and the majority were HBeAg-negative with low viral load; a meta-analysis is underway to assess the performance of HBcrAg in different HBV genotypes, with a wide range of viral load and HBeAg sero-positivity (registered at PROSPERO: CRD42017055440).

Without having simple, affordable, and reliable diagnostic tools to evaluate active HBV replication, it is unlikely to reach the WHO's global elimination goals [39]. HBcrAg, a promising alternative to HBV DNA PCR, warrants further validation. 


\section{Acknowledgement}

We thank all the study participants.

\section{Funding}

This work was supported by the Gambian Ministry of Health and Social Affairs; MRC Unit The Gambia; the European Commission [FP7 grant 265994]; and the Viral Hepatitis Research Foundation of Japan.

\section{Conflict of Interest}

MI, KM, KA are employees of Fujirebio Inc. YS has served as consultant, and MT has received grants from Gilead Sciences. The others authors declare no conflict of interest. 


\section{References}

1. WHO. Global Health Sector Strategy on Viral Hepatitis 2016-2021. Geneva, Switzerland: 2016.

2. Terrault NA, Lok ASF, McMahon BJ, et al. Update on prevention, diagnosis, and treatment of chronic hepatitis B: AASLD 2018 hepatitis B guidance. Hepatology 2018; 67:1560-1599.

3. European Association for the Study of the Liver. EASL 2017 Clinical Practice Guidelines on the management of hepatitis B virus infection. J Hepatol 2017; 67:370-398.

4. Sarin SK, Kumar M, Lau GK, et al. Asian-Pacific clinical practice guidelines on the management of hepatitis B: a 2015 update. Hepatol Int 2016; 10:1-98.

5. WHO. Guidelines for the prevention, care and treatment of persons with chronic hepatitis B infection. Geneva, Switzerland: 2015.

6. Razavi-Shearer D, Gamkrelidze I, Nguyen MH, et al. Global prevalence, treatment, and prevention of hepatitis B virus infection in 2016: a modelling study. Lancet Gastroenterol Hepatol 2018; 3:383-403.

7. Andriamandimby SF, Olive MM, Shimakawa Y, et al. Prevalence of chronic hepatitis B virus infection and infrastructure for its diagnosis in Madagascar: Implication for the WHO's elimination strategy. BMC Public Health 2017; 17:636.

8. WHO. Guidelines on hepatitis B and C testing. Geneva, Switzerland: 2017.

9. Kimura T, Rokuhara A, Sakamoto Y, et al. Sensitive Enzyme Immunoassay for Hepatitis B Virus Core-Related Antigens and Their Correlation to Virus Load Sensitive Enzyme Immunoassay for Hepatitis B Virus Core-Related Antigens and Their Correlation to Virus Load. J Clin Microbiol 2002; 40:439-445.

10. Wong DKH, Tanaka Y, Lai CL, Mizokami M, Fung J, Yuen MF. Hepatitis B virus core- 
related antigens as markers for monitoring chronic hepatitis B infection. J Clin Microbiol 2007; 45:3942-3947.

11. Suzuki F, Miyakoshi H, Kobayashi M, Kumada H. Correlation between serum hepatitis B virus core-related antigen and intrahepatic covalently closed circular DNA in chronic hepatitis B patients. J Med Virol 2009; 81:27-33.

12. Maasoumy B, Wiegand SB, Jaroszewicz J, et al. Hepatitis B core-related antigen (HBcrAg) levels in the natural history of hepatitis B virus infection in a large European cohort predominantly infected with genotypes A and D. Clin Microbiol Infect 2015; 21:606.e1-606.e10.

13. Riveiro-Barciela M, Bes M, Rodríguez-Frías F, et al. Serum hepatitis B core-related antigen is more accurate than hepatitis B surface antigen to identify inactive carriers, regardless of hepatitis B virus genotype. Clin Microbiol Infect 2017; 23:860-867.

14. Wong DKH, Seto WK, Cheung KS, et al. Hepatitis B virus core-related antigen as a surrogate marker for covalently closed circular DNA. Liver Int 2017; 37:995-1001.

15. Testoni B, Lebossé F, Scholtes C, et al. Serum hepatitis B core-related antigen (HBcrAg) correlates with covalently closed circular DNA transcriptional activity in chronic hepatitis B patients. J Hepatol 2019; 70:615-625.

16. Duchesne L, Njouom R, Lissock F, et al. HCV Ag quantification as a one-step procedure in diagnosing chronic hepatitis C infection in Cameroon: The ANRS 12336 study. J Int AIDS Soc 2017; 20:1-8.

17. Mohamed Z, Mbwambo J, Shimakawa Y, et al. Clinical utility of HCV core antigen detection and quantification using serum samples and dried blood spots in people who inject drugs in Dar-es-Salaam, Tanzania. J Int AIDS Soc 2017; 20:21856.

18. Freiman JM, Tran TM, Schumacher SG, et al. Hepatitis C core antigen testing for 
diagnosis of hepatitis $\mathrm{C}$ virus infection: A systematic review and meta-analysis. Ann Intern Med 2016; 165:345-355.

19. Lemoine M, Shimakawa Y, Njie R, et al. Acceptability and feasibility of a screen-and-treat programme for hepatitis B virus infection in The Gambia: the Prevention of Liver Fibrosis and Cancer in Africa (PROLIFICA) study. Lancet Glob Heal 2016; 4:e559-e567.

20. Shimakawa Y, Lemoine M, Njai HF, et al. Natural history of chronic HBV infection in West Africa: a longitudinal population-based study from The Gambia. Gut 2016; 65:20072016.

21. Shimakawa Y, Lemoine M, Bottomley C, et al. Birth order and risk of hepatocellular carcinoma in chronic carriers of hepatitis B virus: a case-control study in The Gambia. Liver Int 2015; 35:2318-2326.

22. Lemoine M, Shimakawa Y, Njie R, et al. Food intake increases liver stiffness measurements and hampers reliable values in patients with chronic hepatitis B and healthy controls: the PROLIFICA experience in The Gambia. Aliment Pharmacol Ther 2014; 39:188-96.

23. Ghosh S, Sow A, Guillot C, et al. Implementation of an in-house quantitative real-time polymerase chain reaction method for Hepatitis B virus quantification in West African countries. J Viral Hepat 2016; 23:897-904.

24. Lemoine M, Shimakawa Y, Nayagam S, et al. The gamma-glutamyl transpeptidase to platelet ratio (GPR) predicts significant liver fibrosis and cirrhosis in patients with chronic HBV infection in West Africa. Gut 2016; 65:1369-76.

25. Shimakawa Y, Bah E, Wild CP, Hall AJ. Evaluation of data quality at the Gambia National Cancer Registry. Int J Cancer 2013; 132:658-65.

26. Shimakawa Y, Njie R, Ndow G, et al. Development of a simple score based on HBeAg 
and ALT for selecting patients for HBV treatment in Africa. J Hepatol 2018; 69:776-784.

27. Bossuyt PM, Reitsma JB, Bruns DE, et al. RESEARCH METHODS \& REPORTING STARD 2015 : an updated list of essential items for. Radiology 2015; 277:826-832.

28. Mak LY, Wong DKH, Cheung KS, Seto WK, Lai CL, Yuen MF. Review article: hepatitis B core-related antigen (HBcrAg): an emerging marker for chronic hepatitis B virus infection. Aliment Pharmacol Ther 2018; 47:43-54.

29. Lai C-L, Wong D, Ip P, et al. Reduction of covalently closed circular DNA with long-term nucleos(t)ide analogue treatment in chronic hepatitis B. J Hepatol 2017; 66:275-281.

30. Cornberg M, Wong VWS, Locarnini S, Brunetto M, Janssen HLA, Chan HLY. The role of quantitative hepatitis B surface antigen revisited. J Hepatol 2017; 66:398-411.

31. Chen EQ, Feng S, Wang ML, et al. Serum hepatitis B core-related antigen is a satisfactory surrogate marker of intrahepatic covalently closed circular DNA in chronic hepatitis B. Sci Rep 2017; 7:1-8.

32. Chuaypen N, Posuwan N, Chittmittraprap S, et al. Predictive role of serum HBsAg and HBcrAg kinetics in patients with $\mathrm{HBeAg}$-negative chronic hepatitis B receiving pegylated interferon-based therapy. Clin Microbiol Infect 2018; 24:306.e7-306.e13.

33. Honda M, Shirasaki T, Terashima T, et al. Hepatitis B virus (HBV) core-related antigen during nucleos(t)ide analog therapy is related to intra-hepatic HBV replication and development of hepatocellular carcinoma. J Infect Dis 2016; 213:1096-1106.

34. Seto WK, Lo YR, Pawlotsky JM, Yuen MF. Chronic hepatitis B virus infection. Lancet 2018; 392:2313-2324.

35. Tada T, Kumada T, Toyoda H, et al. HBcrAg is a predictor of hepatocellular carcinoma development: an analysis using time-dependent receiver operating characteristics. $\mathbf{J}$ Hepatol 2016; 65:48-56. 
36. Tada T, Kumada T, Toyoda H, Kobayashi N, Akita T, Tanaka J. Hepatitis B virus corerelated antigen levels predict progression to liver cirrhosis in hepatitis B carriers. J Gastroenterol Hepatol 2018; 33:918-925.

37. Shimakawa Y, Seck A, Nayagam S, Toure-Kane C, Lemoine M. Screening strategies to prevent mother-to-child transmission of hepatitis B in sub-Saharan Africa. Lancet Gastroenterol Hepatol 2018; 3:222-223.

38. Wen W-H, Chang M-H, Zhao L-L, et al. Mother-to-infant transmission of hepatitis B virus infection: significance of maternal viral load and strategies for intervention. J Hepatol 2013; 59:24-30.

39. Seck A, Ndiaye F, Maylin S, et al. Poor Sensitivity of Commercial Rapid Diagnostic Tests for Hepatitis B e Antigen in Senegal, West Africa. Am J Trop Med Hyg 2018; 99:428-434. 


\section{Figure Legends}

Fig. 1. Flow chart of study participants

Fig. 2. Correlation between HBcrAg \& HBV DNA levels, HBsAg-HQ \& HBV DNA levels, and HBcrAg \& HQ-HBsAg levels

Fig. 3. Receiver operating characteristic curves for HBcrAg, HBsAg-HQ, and HBeAg to indicate serum HBV DNA levels

Fig. 4. Receiver operating characteristic curves for simplified algorithms to indicate treatment eligibility according to the international guidelines 


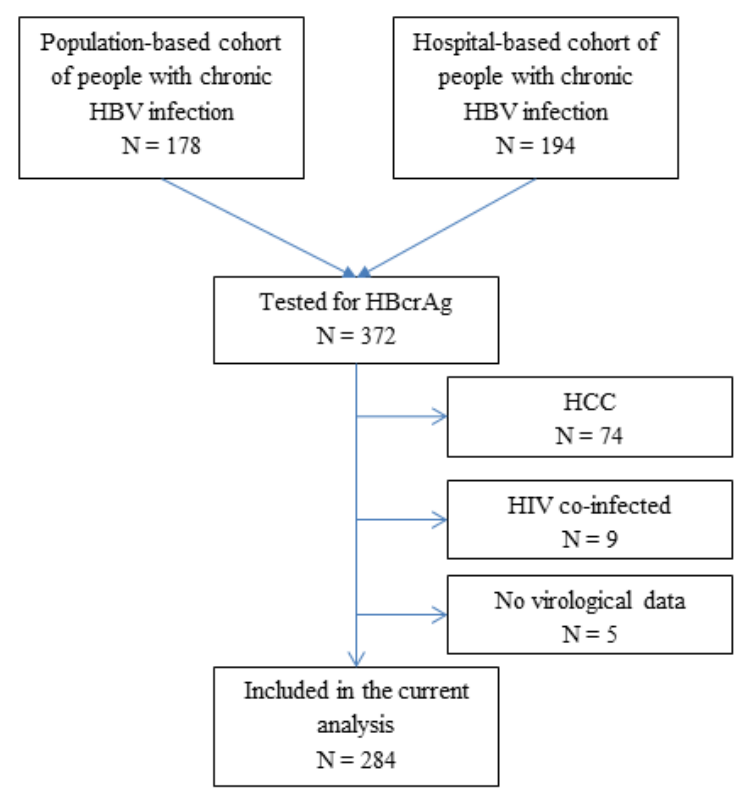

Fig. 1. Flow chart of study participants 

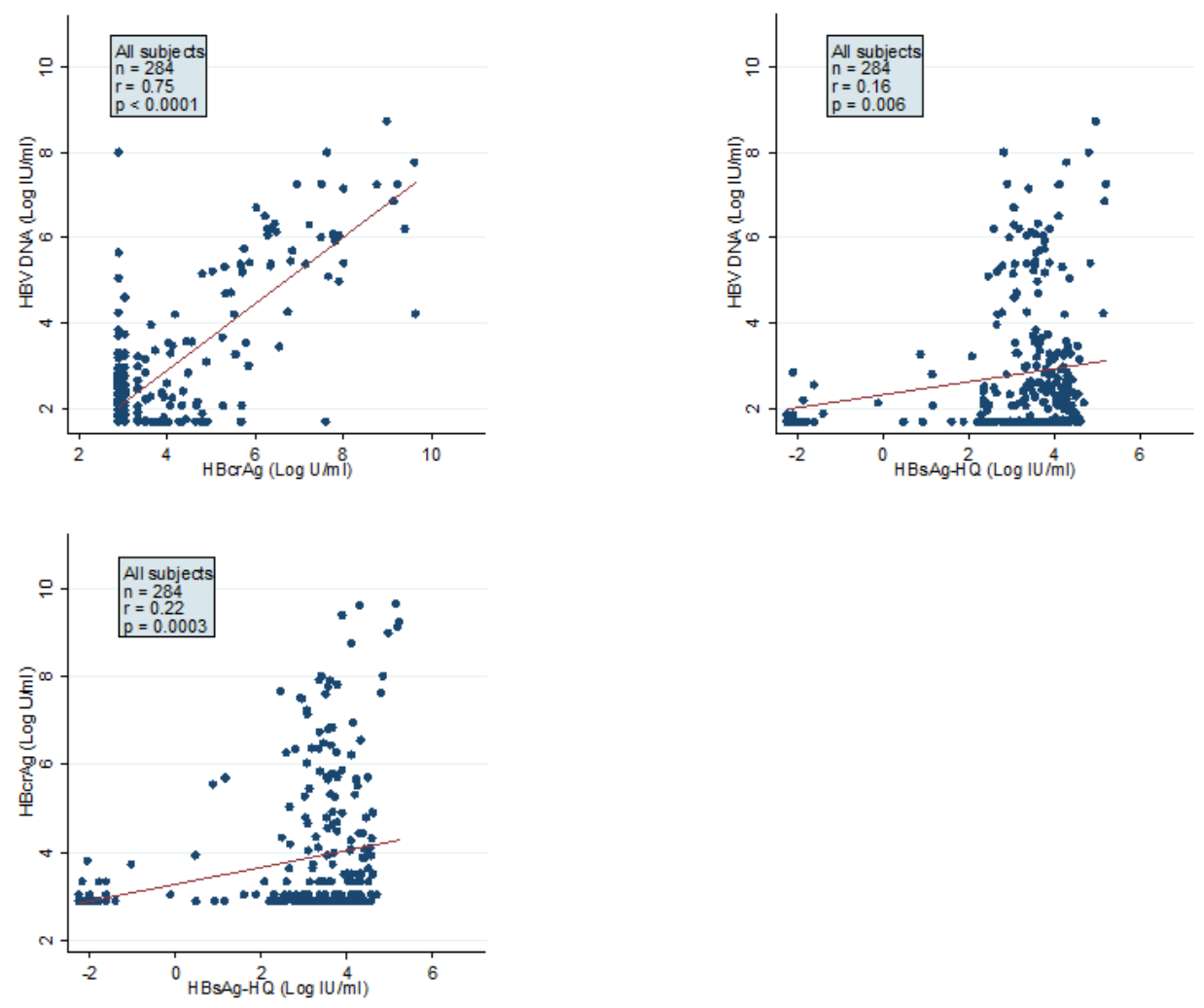

Fig. 2. Correlation between HBcrAg \& HBV DNA levels, HBsAg-HQ \& HBV DNA levels, and HBcrAg \& HQ-HBsAg levels 

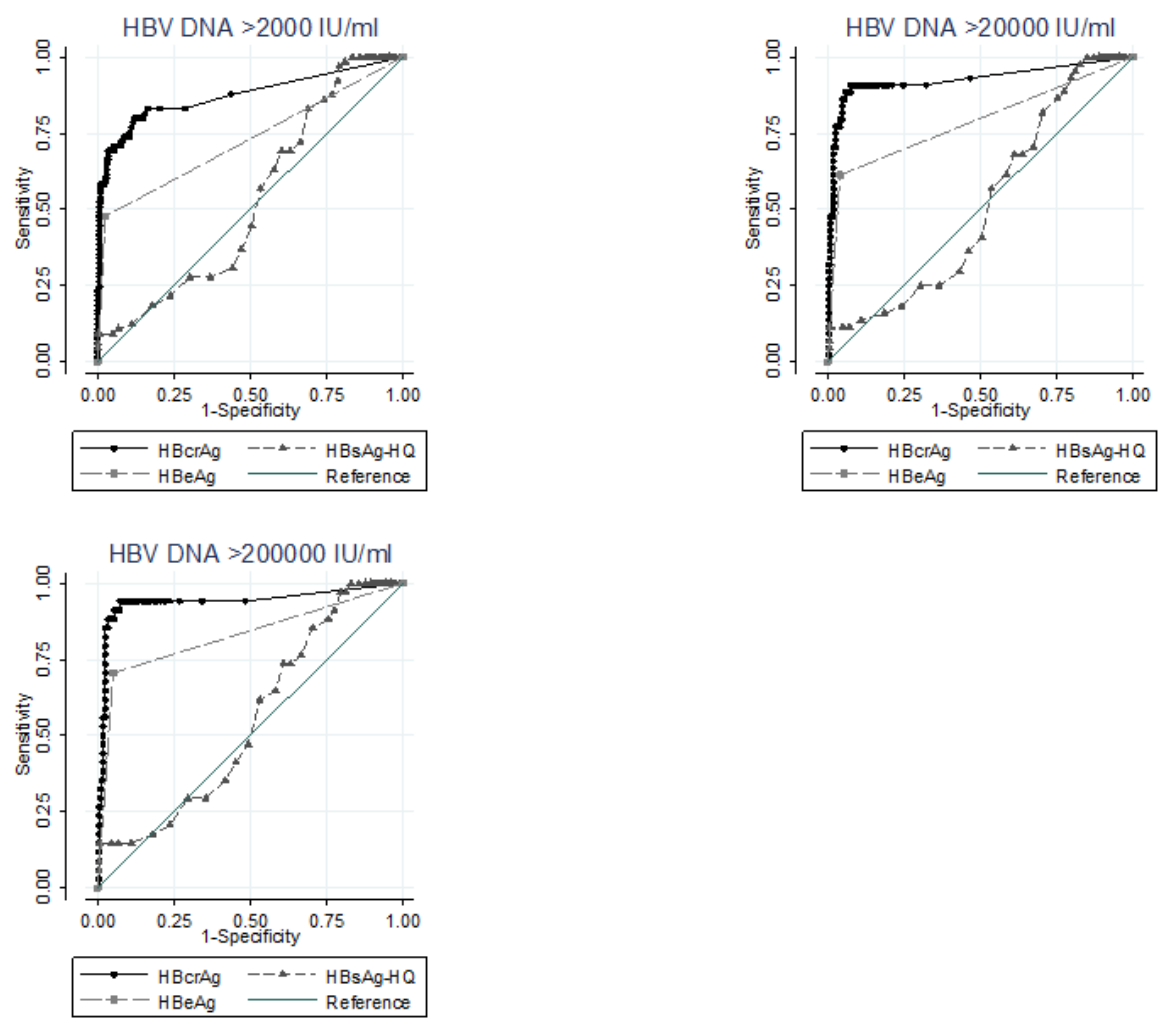

Fig. 3. Receiver operating characteristic curves for $\mathrm{HBcrAg}, \mathrm{HBsAg}-\mathrm{HQ}$, and $\mathrm{HBeAg}$ to indicate serum HBV DNA levels 

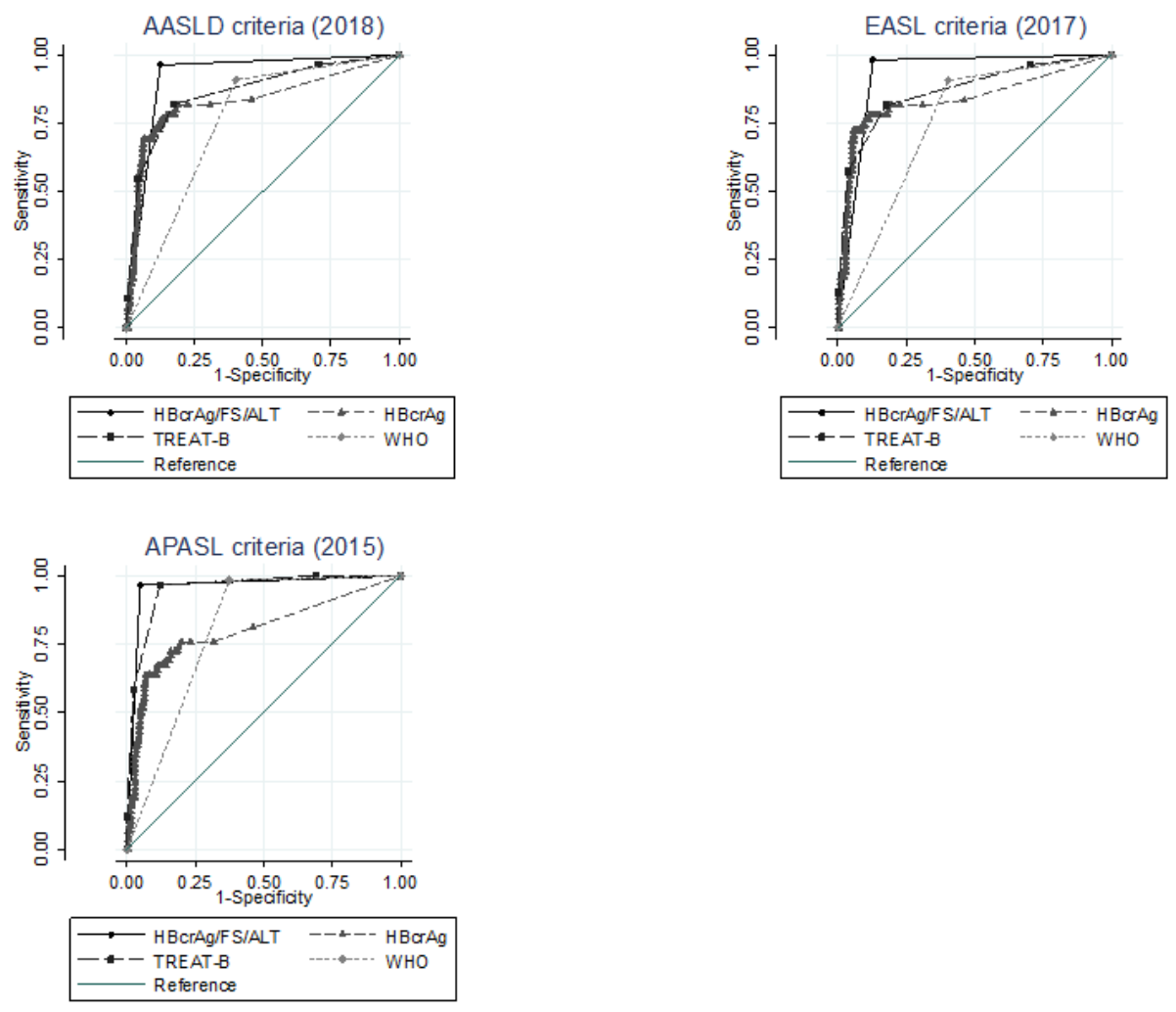

Fig. 4. Receiver operating characteristic curves for simplified algorithms to indicate treatment eligiblity according to the international guidelines 
Table 1. Characteristics of study participants $(n=284)$

\begin{tabular}{|c|c|c|}
\hline \multicolumn{2}{|l|}{ Variables } & Values \\
\hline \multicolumn{2}{|l|}{ Median age (years) } & $36(30-45)$ \\
\hline \multicolumn{2}{|l|}{ Male sex, n (\%) } & $188(66)$ \\
\hline \multicolumn{2}{|c|}{ Ever drunk alcohol, n (\%) } & $24(9)$ \\
\hline \multicolumn{2}{|l|}{ Median BMI $\left(\mathrm{kg} / \mathrm{m}^{2}\right)$} & $22(19-25)$ \\
\hline \multicolumn{2}{|l|}{ Positive HBeAg, n (\%) } & $36(13)$ \\
\hline \multirow[t]{3}{*}{ HBsAg-HQ, n (\%) } & $0.005-1,000 \mathrm{IU} / \mathrm{ml}$ & $83(29)$ \\
\hline & $1,000-10,000 \mathrm{IU} / \mathrm{ml}$ & $109(38)$ \\
\hline & $\geq 10,000 \mathrm{IU} / \mathrm{ml}$ & $92(32)$ \\
\hline \multirow[t]{3}{*}{ HBcrAg, n (\%) } & Undetectable & $132(47)$ \\
\hline & $3.0-4.0 \log \mathrm{U} / \mathrm{ml}$ & $75(26)$ \\
\hline & $\geq 4.0 \log \mathrm{U} / \mathrm{ml}$ & $77(27)$ \\
\hline \multirow[t]{5}{*}{ HBV DNA, n (\%) } & Undetectable & $119(42)$ \\
\hline & $50-2,000 \mathrm{IU} / \mathrm{ml}$ & $99(35)$ \\
\hline & $2,000-20,000 \mathrm{IU} / \mathrm{ml}$ & $21(7)$ \\
\hline & $20,000-200,000 \mathrm{IU} / \mathrm{ml}$ & $10(4)$ \\
\hline & $\geq 200,000 \mathrm{IU} / \mathrm{ml}$ & $35(12)$ \\
\hline \multirow{2}{*}{ HBV genotype, n (\%) } & A & $38(16)$ \\
\hline & $\mathrm{E}$ & $198(84)$ \\
\hline \multicolumn{2}{|c|}{ Median liver stiffness $(\mathrm{kPa})$} & $5.8(4.5-10.7)$ \\
\hline \multicolumn{2}{|l|}{ Liver cirrhosis, n (\%) } & $55(19)$ \\
\hline \multicolumn{2}{|l|}{ Median AST (IU/L) } & $33(26-53)$ \\
\hline \multicolumn{2}{|l|}{ Median ALT (IU/L) } & $25(19-42)$ \\
\hline \multicolumn{2}{|l|}{ Median GGT (IU/L) } & $31(22-70)$ \\
\hline \multicolumn{2}{|l|}{ Median albumin $(\mathrm{g} / \mathrm{L})$} & $41(36-44)$ \\
\hline \multicolumn{2}{|c|}{ Median total bilirubin (IU/L) } & $11(8-18)$ \\
\hline \multicolumn{2}{|l|}{ Median platelets $\left(10^{9} / \mathrm{L}\right)$} & $180(130-242)$ \\
\hline \multicolumn{2}{|c|}{ Eligible for AASLD treatment criteria (2018), n (\%) } & $59(21)$ \\
\hline
\end{tabular}




\begin{tabular}{|l|l|}
\hline Eligible for EASL treatment criteria (2017), n (\%) & $58(20)$ \\
\hline Eligible for APASL treatment criteria (2015), n (\%) & $63(22)$ \\
\hline Eligible for WHO treatment criteria for LMICs (2015), n (\%) & $140(49)$ \\
\hline
\end{tabular}

Continuous variables are presented as median (interquartile range). 
Table 2. Performance of serum HBcrAg levels, HBsAg-HQ levels and HBeAg to discriminate clinically important HBV DNA levels

\begin{tabular}{|c|c|c|c|c|c|c|c|c|c|}
\hline & \multicolumn{9}{|c|}{ HBV DNA levels } \\
\hline & \multicolumn{3}{|c|}{$2,000 \mathrm{IU} / \mathrm{ml}$} & \multicolumn{3}{|c|}{$20,000 \mathrm{IU} / \mathrm{ml}$} & \multicolumn{3}{|c|}{$200,000 \mathrm{IU} / \mathrm{ml}$} \\
\hline & HBcrAg & HBsAg & HBeAg & HBcrAg & HBsAg & HBeAg & HBcrAg & HBsAg & HBeAg \\
\hline AUROC (95\% CI) & $\begin{array}{c}0.88 \\
(0.82- \\
0.93)\end{array}$ & $\begin{array}{c}0.55 \\
(0.48- \\
0.62)\end{array}$ & $\begin{array}{c}0.73 \\
(0.66- \\
0.79)\end{array}$ & $\begin{array}{c}0.92 \\
(0.87- \\
0.98)\end{array}$ & $\begin{array}{c}0.53 \\
(0.45- \\
0.61)\end{array}$ & $\begin{array}{c}0.79 \\
(0.71- \\
0.86)\end{array}$ & $\begin{array}{c}0.94 \\
(0.88- \\
0.99)\end{array}$ & $\begin{array}{c}0.56 \\
(0.47- \\
0.66)\end{array}$ & $\begin{array}{c}0.83 \\
(0.75- \\
0.91)\end{array}$ \\
\hline P-value (compared to HBcrAg) & N/A & $<0.001$ & $<0.001$ & N/A & $<0.001$ & $<0.001$ & N/A & $<0.001$ & 0.004 \\
\hline Cut-off & $\begin{array}{c}3.6 \mathrm{log} \\
\mathrm{U} / \mathrm{ml}\end{array}$ & $\begin{array}{l}3.6 \log \\
\mathrm{IU} / \mathrm{ml}\end{array}$ & Positive & $\begin{array}{c}4.8 \mathrm{log} \\
\mathrm{U} / \mathrm{ml}\end{array}$ & $\begin{array}{l}3.6 \mathrm{log} \\
\mathrm{IU} / \mathrm{ml}\end{array}$ & Positive & $\begin{array}{c}5.3 \mathrm{log} \\
\mathrm{U} / \mathrm{ml}\end{array}$ & $\begin{array}{l}3.7 \mathrm{log} \\
\mathrm{IU} / \mathrm{ml}\end{array}$ & Positive \\
\hline Sensitivity (\%) & 83.3 & 56.1 & 47.7 & 88.9 & 55.6 & 61.4 & 91.4 & 45.7 & 70.6 \\
\hline Specificity (\%) & 83.9 & 49.5 & 97.6 & 92.9 & 49.0 & 96.0 & 93.2 & 53.0 & 94.9 \\
\hline Positive predictive value $(\%)$ & 61.1 & 25.2 & 86.1 & 70.2 & 17.0 & 75.0 & 65.3 & 12.0 & 66.7 \\
\hline Negative predictive value $(\%)$ & 94.3 & 78.8 & 85.5 & 97.8 & 85.4 & 92.8 & 98.7 & 87.4 & 95.7 \\
\hline Positive likelihood ratio & 5.2 & 1.1 & 19.6 & 12.5 & 1.1 & 15.5 & 13.4 & 1.0 & 13.9 \\
\hline Negative likelihood ratio & 0.2 & 0.9 & 0.5 & 0.1 & 0.9 & 0.4 & 0.1 & 1.0 & 0.3 \\
\hline
\end{tabular}


Table 3. Virological factors associated with significant liver fibrosis and elevated ALT levels

\begin{tabular}{|c|c|c|c|c|c|c|}
\hline \multicolumn{2}{|c|}{ 1. Association with significant liver fibrosis } & \multirow{3}{*}{$\begin{array}{c}\begin{array}{c}\text { Significant liver } \\
\text { fibrosis }(\%)\end{array} \\
20 \%\end{array}$} & \multicolumn{2}{|c|}{ Crude } & \multicolumn{2}{|c|}{ Adjusted* } \\
\hline & & & \multirow{2}{*}{$\begin{array}{c}\text { OR }(95 \% \mathrm{CI}) \\
1.0\end{array}$} & \multirow{4}{*}{$\begin{array}{c}\text { p-value } \\
<0.001\end{array}$} & \multirow{2}{*}{$\begin{array}{c}\text { OR }(95 \% \mathrm{CI}) \\
1.0\end{array}$} & \multirow{2}{*}{$\begin{array}{c}\text { p-value } \\
<0.001\end{array}$} \\
\hline $\mathrm{HBcrAg}$ & $<3.6 \log \mathrm{U} / \mathrm{ml}$ & & & & & \\
\hline \multirow{2}{*}{$(\log \mathrm{U} / \mathrm{ml})$} & $3.6-5.3 \log \mathrm{U} / \mathrm{ml}$ & $37 \%$ & $2.3(1.1-4.7)$ & & $2.6(1.2-5.8)$ & \\
\hline & $\geq 5.3 \log \mathrm{U} / \mathrm{ml}$ & $67 \%$ & $8.2(4.1-16.4)$ & & $19.7(4.3-91.1)$ & \\
\hline \multirow[t]{2}{*}{ HBsAg-HQ } & $<3.6 \log \mathrm{IU} / \mathrm{ml}$ & $35 \%$ & 1.0 & \multirow[t]{2}{*}{0.2} & & \\
\hline & $\geq 3.6 \log \mathrm{IU} / \mathrm{ml}$ & $27 \%$ & $0.7(0.4-1.1)$ & & & \\
\hline \multirow[t]{2}{*}{$\mathrm{HBeAg}$} & Negative & $26 \%$ & 1.0 & \multirow[t]{2}{*}{$<0.001$} & 1.0 & \multirow[t]{2}{*}{0.4} \\
\hline & Positive & $61 \%$ & $4.6(2.2-9.5)$ & & $0.6(0.2-2.1)$ & \\
\hline \multirow[t]{2}{*}{ HBV DNA } & Undetectable & $25 \%$ & 1.0 & \multirow[t]{4}{*}{$<0.001$} & 1.0 & \multirow[t]{4}{*}{0.8} \\
\hline & $50-2,000$ & $24 \%$ & $1.0(0.5-1.8)$ & & $1.0(0.5-2.1)$ & \\
\hline \multirow{2}{*}{ (IU/ml) } & $2,000-200,000$ & $39 \%$ & $1.9(0.8-4.3)$ & & $0.7(0.2-2.0)$ & \\
\hline & $\geq 200,000$ & $60 \%$ & $4.5(2.0-9.8)$ & & $0.6(0.1-2.5)$ & \\
\hline \multirow[t]{2}{*}{ HBV genotype } & $\mathrm{E}$ & $29 \%$ & 1.0 & \multirow[t]{2}{*}{1.0} & & \\
\hline & $\mathrm{A}$ & $29 \%$ & $1.0(0.5-2.2)$ & & & \\
\hline \multirow{2}{*}{\multicolumn{2}{|c|}{ 2. Association with elevated ALT ( $\geq 40$ IU/L) }} & ALT $\geq 40$ IU/L & \multicolumn{2}{|c|}{ Crude } & \multicolumn{2}{|c|}{ Adjusted* } \\
\hline & & & OR $(95 \% \mathrm{CI})$ & p-value & OR $(95 \% \mathrm{CI})$ & p-value \\
\hline \multirow[t]{2}{*}{$\mathrm{HBcrAg}$} & $<3.6 \log \mathrm{U} / \mathrm{ml}$ & $15 \%$ & 1.0 & \multirow[t]{2}{*}{$<0.001$} & 1.0 & \multirow[t]{2}{*}{0.003} \\
\hline & $3.6-5.3 \log \mathrm{U} / \mathrm{ml}$ & $29 \%$ & $2.3(1.0-5.3)$ & & $1.9(0.8-4.7)$ & \\
\hline
\end{tabular}




\begin{tabular}{|c|c|c|c|c|c|c|}
\hline$(\log \mathrm{U} / \mathrm{ml})$ & $\geq 5.3 \log \mathrm{U} / \mathrm{ml}$ & $73 \%$ & $15.5(7.3-32.9)$ & & $12.0(2.8-50.6)$ & \\
\hline HBsAg-HQ & $<3.6 \log \mathrm{IU} / \mathrm{ml}$ & $31 \%$ & 1.0 & \multirow[t]{2}{*}{0.1} & & \\
\hline$(\log \mathrm{IU} / \mathrm{ml})$ & $\geq 3.6 \log \mathrm{IU} / \mathrm{ml}$ & $23 \%$ & $0.6(0.4-1.1)$ & & & \\
\hline \multirow[t]{2}{*}{$\mathrm{HBeAg}$} & Negative & $20 \%$ & 1.0 & \multirow[t]{2}{*}{$<0.001$} & 1.0 & \multirow[t]{2}{*}{0.7} \\
\hline & Positive & $69 \%$ & $8.7(4.0-19.0)$ & & $0.8(0.2-3.0)$ & \\
\hline \multirow[t]{2}{*}{ HBV DNA } & Undetectable & $18 \%$ & 1.0 & \multirow[t]{4}{*}{$<0.001$} & 1.0 & \multirow[t]{4}{*}{0.4} \\
\hline & $50-2,000$ & $15 \%$ & $0.8(0.4-1.6)$ & & $0.8(0.4-1.8)$ & \\
\hline \multirow{2}{*}{ (IU/ml) } & $2,000-200,000$ & $48 \%$ & $4.2(1.8-10.0)$ & & $2.0(0.7-5.8)$ & \\
\hline & $\geq 200,000$ & $71 \%$ & $11.2(4.7-26.8)$ & & $1.7(0.4-6.9)$ & \\
\hline \multirow[t]{2}{*}{ HBV genotype } & $\mathrm{E}$ & $26 \%$ & 1.0 & \multirow[t]{2}{*}{0.9} & & \\
\hline & $\mathrm{A}$ & $27 \%$ & $1.0(0.5-2.3)$ & & & \\
\hline
\end{tabular}

* The variables significantly associated with the outcomes in the crude analyses $(\mathrm{p}<0.05)$ were mutually adjusted. 
Table 4. Performance of simplified algorithm using HBcrAg, TREAT-B and WHO criteria to select patients eligible for antiviral therapy

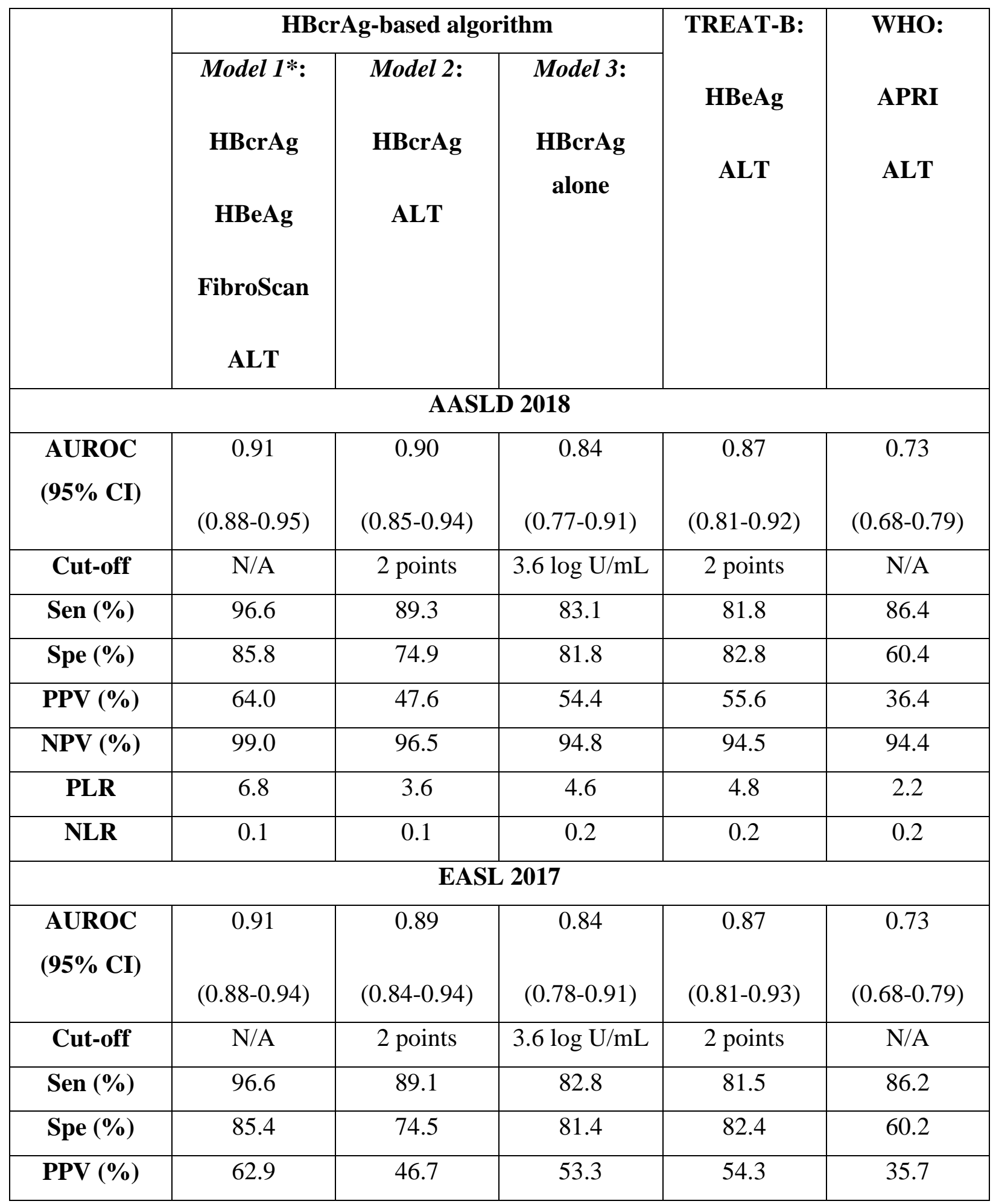




\begin{tabular}{|c|c|c|c|c|c|}
\hline NPV (\%) & 99.0 & 96.5 & 94.8 & 94.5 & 94.4 \\
\hline PLR & 6.6 & 3.5 & 4.5 & 4.6 & 2.2 \\
\hline NLR & 0.1 & 0.1 & 0.2 & 0.2 & 0.2 \\
\hline \multicolumn{5}{|c|}{ APASL 2015 } \\
\hline AUROC \\
(95\% CI)
\end{tabular}

* Model 1 is described in details in Supplementary Table 3. 